\title{
Tubo-ovarian abscess with sepsis in a nonagenarian woman: a case report and literature review
}

\author{
Kuan-Yi Chen ${ }^{1}$, Jen-Yu Tseng ${ }^{2,6}$ and Chih-Yu Yang ${ }^{3,4,5,6^{*}}$ (D)
}

\begin{abstract}
Background: A complete infectious focus survey relies on a thorough physical examination as well as a pelvic examination. Tubo-ovarian abscess, though less likely to occur in senior women, may become a life-threatening disease requiring emergent surgery. Hence, clinical awareness and aggressive management are warranted to avoid delayed diagnosis and subsequent complications.

Case presentation: We report a post-menopausal woman presented with sepsis of unknown origin, which turned out to be a huge tubo-ovarian abscess. Although tubo-ovarian abscess mostly occurs in women of fertile age, it is likely that the immune status of our post-menopausal patient was compromised because of old age and uremia. Moreover, due to underlying dementia, she could not express her discomfort in the early stage. Her sepsis resolved after a unilateral salpingo-oophorectomy surgery and antibiotic treatment. It is crucial to exclude pelvic inflammatory disease (PID) if no specific source of infection can be identified.

Conclusions: Rupture of the tubo-ovarian abscess is a condition of high mortality rate. Although tubo-ovarian abscess is more likely to develop in patients aged 15-25 years old, the tubo-ovarian abscess should be listed as a differential diagnosis in all post-menopausal women, especially those who are immunocompromised or with a palpable pelvic mass, to enable timely management and better prognosis.
\end{abstract}

Keywords: Fever of unknown origin, Tubo-ovarian abscess, Post-menopausal, Nonagenarian, Chronic kidney disease, Case report

\section{Background}

Tubo-ovarian abscess, one entity of pelvic inflammatory diseases (PID), mostly occurs in women of fertile age and may become a life-threatening condition requiring emergent surgery. Therefore, in order to ensure early recognition, it is essential to exclude PID if no specific source of infection can be identified, even in elderly post-menopausal women. In this report, we highlight the pivotal role of pelvic examination in a thorough infectious focus work-up.

\footnotetext{
*Correspondence: cyyang3@vghtpe.gov.tw

${ }^{3}$ Division of Nephrology, Department of Medicine, Taipei Veterans General Hospital, Taipei, Taiwan

${ }^{4}$ Institute of Clinical Medicine, School of Medicine, National Yang-Ming

University, Taipei, Taiwan

Full list of author information is available at the end of the article
}

\section{Case presentation}

A 91-year-old post-menopausal woman without diabetes mellitus or hypertension presented with shortness of breath, fever up to 38.5 degrees, anuria, and conscious disturbance for two days. Tracing back her history, she has dementia for 20 years with chronic kidney disease in stage 5 , and she has not received any bowel or adnexal surgery. Last year, a transvaginal ultrasound had been performed by the gynecologist for a palpable pelvic mass, but only endometrial hyperplasia was impressed. Upon this admission, physical examination revealed a palpable mass as well, but there was no evident tenderness initially. Her body mass index was $23 \mathrm{Kg} / \mathrm{m}^{2}$. Laboratory test showed leukocytosis, azotemia with blood urea nitrogen $117 \mathrm{mg} /$ $\mathrm{dL}$, creatinine $12.9 \mathrm{mg} / \mathrm{dL}$, C-reactive protein $26.2 \mathrm{mg} / \mathrm{dL}$, procalcitonin $2.5 \mathrm{ng} / \mathrm{mL}$, and pyuria. We initiated hemodialysis therapy for her uremia. Stool routine and

(c) The Author(s). 2019 Open Access This article is distributed under the terms of the Creative Commons Attribution 4.0 International License (http://creativecommons.org/licenses/by/4.0/), which permits unrestricted use, distribution, and 
culture showed negative results, indicating that colitis or gastrointestinal bleeding is less likely.

After two weeks of antibiotic treatment, leukocytosis, pyuria, and sepsis resolved, but intermittent fever lasted along with pelvic tenderness. We thus consulted the gynecologist again, who then arranged an urgent abdominal computed tomography (CT) because of the highly possible surgical requirement upon consultation. The CT scan disclosed the presence of a huge cystic mass $13.5 \times 11.8 \mathrm{~cm}$ with internal septation and mural solid component without any obvious fat stranding at lower abdomen nor any evidence of acute colitis. The urinary bladder was compressed by it (Fig. 1). No significant enlarged lymph nodes were found. Mucinous cystadenoma with ovarian torsion was suspected, and thus surgical intervention was arranged. During the surgery, a $12 \times 10 \times 10 \mathrm{~cm}$ right tubo-ovarian abscess with $800 \mathrm{~mL}$ of pus-like content was drained. Right salpingo-oophorectomy and pus culture were performed. The pathological examination showed ovarian tissue with acute and chronic inflammation, inflammatory exudate, and granulation tissue formation, which were compatible with that of a tubo-ovarian abscess, and its pus culture yielded Escherichia coli. Antibiotics were administered based on the culture sensitivity test, and her infection ultimately resolved thereafter.

\section{Discussion and conclusions}

In a case series which enrolled 80 tubo-ovarian abscess patients, their age ranged from 15 to 69 years old with an average of 42 years old [1]. In another retrospective study enrolled 63 patients with a surgically confirmed tuboovarian abscess, only nine patients were post-menopausal [2], contrasting the rarity of our case who is a nonagenarian. Similarly, literature regarding tubo-ovarian abscess showed that the average age ranges 52-58-year-old in the post-menopausal group, as shown in Table 1 [1-10]. The risk factors for tubo-ovarian abscess include age between 15 to 25 years old, a prior history of pelvic inflammatory disease, and multiple sexual partners.

Heaton et al. reported 20 post-menopausal women with a tubo-ovarian abscess in a case series; only $20 \%$ of patients were febrile, $45 \%$ presenting with leukocytosis, and $55 \%$ having a palpable pelvic mass [11]. In our patient, fever and leukocytosis were presented initially. However, due to her underlying dementia, the patient could not express her discomfort. Meanwhile, the initial physical examination did not reveal any acute abdominal sign, leading to delayed recognition of tubo-ovarian abscess in our case. Hsiao et al. analyzed 74 patients with surgically proved tubo-ovarian abscess, they found that an accurate preoperative diagnosis of the tubo-ovarian abscess was significantly lower in the post-menopausal group as compared to the pre-menopausal group (22\% versus $54 \%$ ), indicating a highly prevalent silent presentation of tubo-ovarian abscess in the post-menopausal group [12]. Also, another predisposing factor of our patient may be her immunocompromised status because of advanced age and uremia, usually manifesting as reduced antigenpresenting dendritic cells, depletion of naïve and central memory $\mathrm{T}$ cells and B cells, and impaired phagocytic function of neutrophils and monocytes [13].

Because rupture of a tubo-ovarian abscess is a lifethreatening emergency, aggressive medical or surgical management is required immediately [14]. Therefore, during infection work-up, clinicians should always consider PID to avoid delayed management, even if patients are more than 70 years old, as is our patient. A complete infectious focus survey relies on a thorough physical examination as well as a pelvic examination. Also, the tubo-ovarian abscess should be listed as a differential diagnosis in all post-menopausal women, especially those who are immunocompromised or with a palpable pelvic mass, to enable timely management and better prognosis.
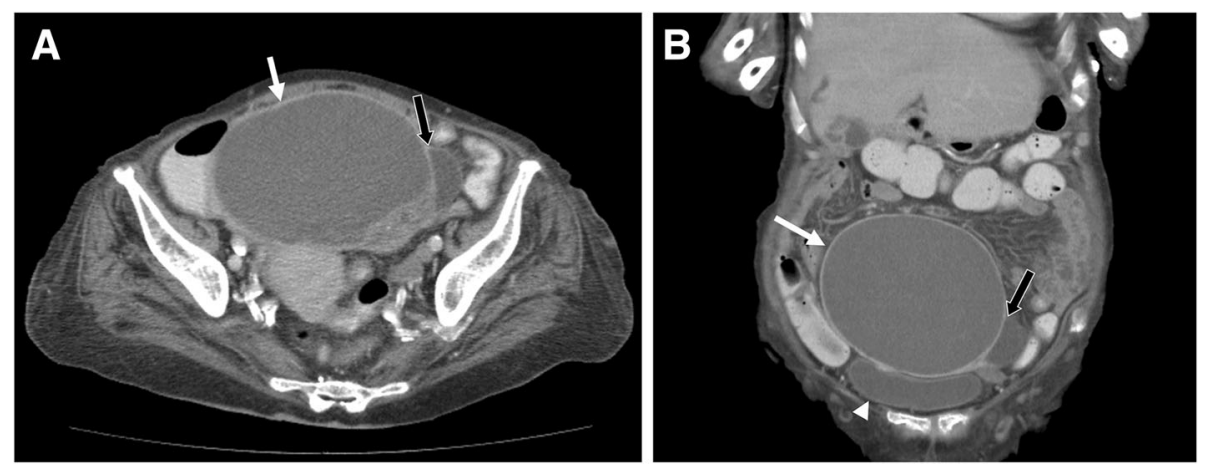

Fig. 1 An abdominal computed tomography demonstrated the presence of a huge cystic mass $13.5 \times 11.8 \mathrm{~cm}$ (white arrows) with internal septation (panel $\mathbf{a}$, black arrows) and solid mural component. The urinary bladder (panel $\mathbf{b}$, arrowhead) was compressed by it. No significant enlarged lymph nodes were found 


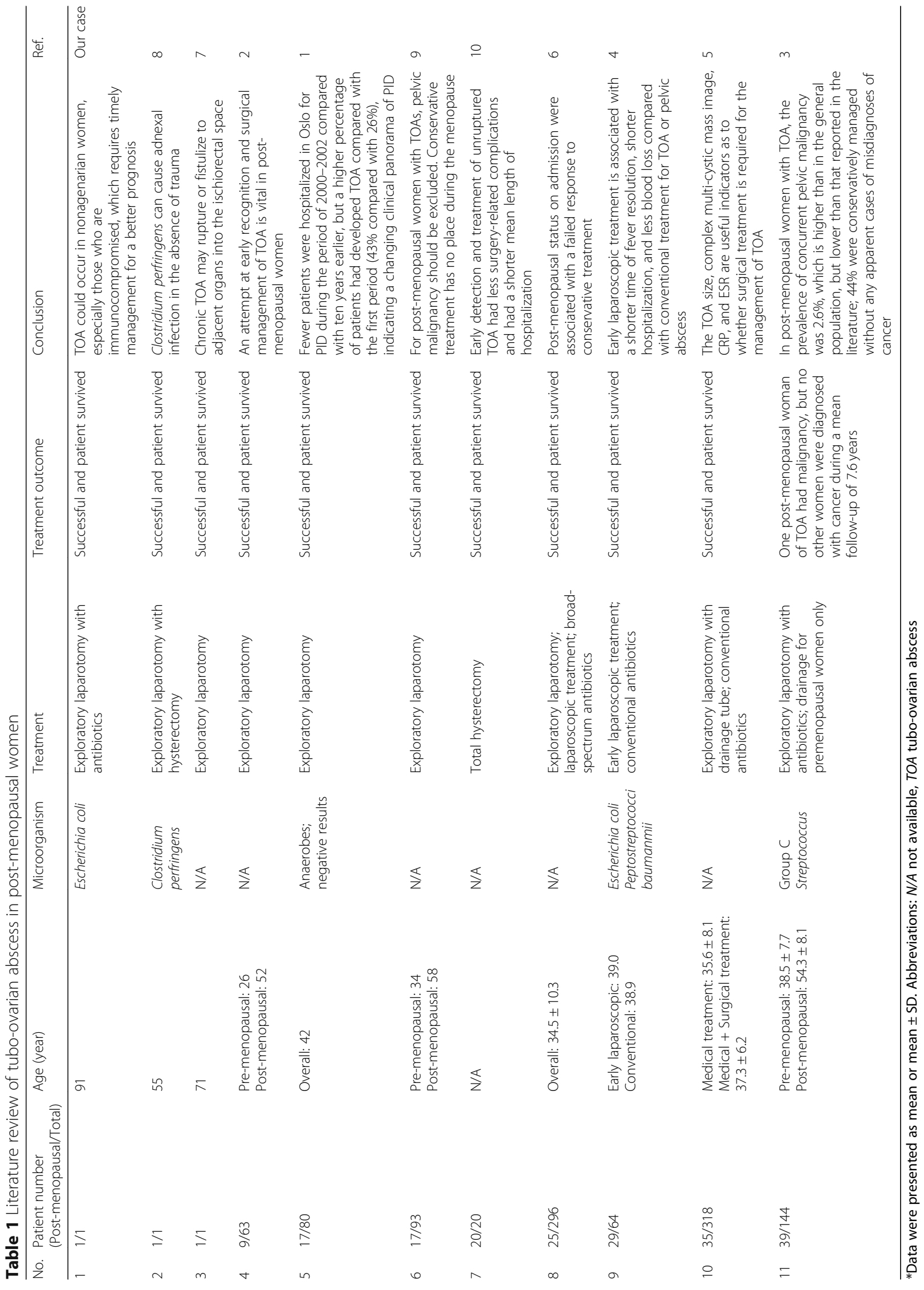




\section{Abbreviation}

PID: Pelvic inflammatory disease

\section{Acknowledgements}

Not applicable.

\section{Authors' contributions}

Drafting manuscript: $\mathrm{KC}$ and $\mathrm{CY}$. Revising manuscript content: JT and $\mathrm{CY}$. Approving final version of manuscript: $\mathrm{KC}$, JT, and $\mathrm{CY}$. All authors make a significant contribution to the project and give final approval of the submitted manuscript.

\section{Funding}

This work was in part supported for research purpose by the "Development and Construction Plan" of the School of Medicine, National YangMingUniversity, Taiwan (107F-M01), the Ministry of Science and Technology, Taiwan (MOST 108-2633-B-009-001), and Taipei Veterans General Hospital, Taiwan (V106D25-003-MY3). The funders have no role in study design, data collection, analysis, and interpretation, or in writing of the manuscript.

\section{Availability of data and materials}

All data presented in this report are included in this published article.

\section{Ethics approval and consent to participate}

Not applicable.

\section{Consent for publication}

The son of the patient who was described in this case report had given

written informed consent for the publication of this case report.

\section{Competing interests}

The authors declare that they have no competing interests.

\section{Author details}

'Department of Chest Medicine, Taipei Veterans General Hospital, Taipei, Taiwan. ${ }^{2}$ Department of Obstetrics and Gynecology, Taipei Veterans General Hospital, Taipei, Taiwan. ${ }^{3}$ Division of Nephrology, Department of Medicine, Taipei Veterans General Hospital, Taipei, Taiwan. ${ }^{4}$ Institute of Clinical Medicine, School of Medicine, National Yang-Ming University, Taipei, Taiwan. ${ }^{5}$ Stem Cell Research Center, National Yang-Ming University, Taipei, Taiwan. ${ }^{6}$ School of Medicine, National Yang-Ming University, No. 201, Section 2, Shih-Pai Road, Taipei 11217, Taiwan.

Received: 24 October 2018 Accepted: 14 June 2019

Published online: 19 June 2019

\section{References}

1. Sorbye IK, Jerve F, Staff AC. Reduction in hospitalized women with pelvic inflammatory disease in Oslo over the past decade. Acta Obstet Gynecol Scand. 2005;84(3):290-6.

2. Hoffman M, Molpus K, Roberts WS, Lyman GH, Cavanagh D. Tuboovarian abscess in postmenopausal women. J Reprod Med. 1990;35(5):525-8.

3. Yagur Y, Weitzner O, Man-El G, Schonman R, Klein Z, Fishman A, et al. Conservative management for postmenopausal women with tubo-ovarian abscess. Menopause. 2019.

4. Chu L, Ma H, Liang J, Li L, Shen A, Wang J, et al. Effectiveness and adverse events of early laparoscopic therapy versus conservative treatment for Tubo-ovarian or pelvic abscess: a single-center retrospective cohort study. Gynecol Obstet Investig. 2019:1-9.

5. Inal ZO, Inal HA, Gorkem U. Experience of Tubo-ovarian abscess: a retrospective clinical analysis of 318 patients in a single tertiary Center in Middle Turkey. Surg Infect. 2018;19(1):54-60.

6. Gungorduk K, Guzel E, Asicioglu O, Yildirim G, Ataser G, Ark C, et al. Experience of tubo-ovarian abscess in western Turkey. Int J Gynaecol Obstet. 2014;124(1):45-50.

7. Belli EV, Landmann RG, Koonce SL, Chen AH, Metzger PP. Persistent ischiorectal fistula with supralevator origin secondary to a chronic tuboovarian abscess: report of a case and review of the literature. Female Pelvic Med Reconstr Surg. 2012;18(1):66-7.
8. Wagner A, Russell C, Ponterio JM, Pessolano JC. Ruptured tuboovarian abscess and septic shock with Clostridium perfringens in a postmenopausal woman: a case report. J Reprod Med. 2009;54(10):652-4.

9. Protopapas AG, Diakomanolis ES, Milingos SD, Rodolakis AJ, Markaki SN Vlachos GD, et al. Tubo-ovarian abscesses in postmenopausal women: gynecological malignancy until proven otherwise? Eur J Obstet Gynecol Reprod Biol. 2004;114(2):203-9.

10. Chao AS, Chang SY, Soong YK. Postmenopausal tuboovarian abscess. Changgeng Yi Xue Za Zhi. 1992;15(3):128-33.

11. Heaton FC, Ledger WJ. Postmenopausal tuboovarian abscess. Obstet Gynecol. 1976;47(1):90-4.

12. Hsiao SM, Hsieh FJ, Lien YR. Tuboovarian abscesses in postmenopausal women. Taiwanese J Obstet Gynecol. 2006;45(3):234-8.

13. Vaziri ND, Pahl MV, Crum A, Norris K. Effect of uremia on structure and function of immune system. J Ren Nutr. 2012;22(1):149-56.

14. Pedowitz P, Bloomfield RD. Ruptured adnexal abscess (Tuboovarian) with generalized peritonitis. Am J Obstet Gynecol. 1964;88:721-9.

\section{Publisher's Note}

Springer Nature remains neutral with regard to jurisdictional claims in published maps and institutional affiliations.

\section{Ready to submit your research? Choose BMC and benefit from:}

- fast, convenient online submission

- thorough peer review by experienced researchers in your field

- rapid publication on acceptance

- support for research data, including large and complex data types

- gold Open Access which fosters wider collaboration and increased citations

- maximum visibility for your research: over $100 \mathrm{M}$ website views per year

At BMC, research is always in progress.

Learn more biomedcentral.com/submissions 